\title{
A RADIOLOGICAL STUDY OF THE RELATIONSHIP BETWEEN TUBERCULOSIS AND PNEUMOKONIOSIS IN COAL MINERS
}

\author{
BY \\ K. J. MANN \\ From the Pneumokoniosis Research Unit (South Wales) of the Medical Research Council
}

(RECEIVED FOR PUbLICATION DECEMBeR 4, 1950)

The purpose of this investigation was to study the relationship between the lesions produced in the lung by tuberculous infection on the one hand and coal dust inhalation on the other, by the scrutiny of a large number of chest radiographs of coal miners.

Previous investigations into the relationship between tuberculosis and coal miner's pneumokoniosis have been summarized by Hart and Aslett (1942). These investigations were all either post-mortem studies, clinical studies, or reviews of compensation and mortality statistics. From them the general conclusion was drawn that coal miners with pneumokoniosis had a tendency to develop tuberculosis as a complicating infection, often in a modified form, so that it was not easy to recognize clinically and might even be difficult to determine at necropsy. Mortality statistics confirmed the classical view that there was a low respiratory tuberculosis mortality among miners in general and among bituminous miners in particular, but suggested that the view must be modified for anthracite miners in whom more recent figures had shown an increased tuberculous mortality. Hart and Aslett put forward the hypothesis that occupational environment (the inhalation of coal dust) might be a protection from tuberculosis unless pneumokoniosis occurred, in which case subsequent development of the infection might be favoured. Belt and Ferris (1942) suggested that the formation of collagenous fibrosis in cases of coal miner's pneumokoniosis might be due to the intervention of tuberculosis even though no direct evidence of its presence was obtainable in many cases. In considering those cases where they could identify tuberculosis, which they called "koniophthisis," they concluded that "dust reticulation, by virtue of its silicotic character, evidently favours the inception of tuberculosis and modifies its course." Gough (1947) supported this suggestion. He proposed that tuberculosis was the chief, if not the sole, agent in producing the distinct collagenous nodules which are to be distinguished in certain cases of coal miner's pneumokoniosis from the non-collagenous dust foci. These "infective nodules" appear to form the basis on which massive fibrosis later develops. Rogers (1946) reported that she had evidence of tuberculosis in over $75 \%$ of her cases of massive fibrosis at necropsy. In a smaller series of 20 cases Sladden (1947) observed a similar proportion. However, Gooding (1946) found evidence of tuberculosis in only $26 \%$ of his cases, but he did not say 
how many had massive fibrosis. James (1948) found bacteriological evidence of tuberculosis in $38.5 \%$ of 140 lungs of patients dying with massive fibrosis due to pneumokoniosis. This recent bacteriological work supports the contention that tuberculosis may play a part in the development of massive fibrosis. Other evidence on this question has been summarized by Fletcher (1948).

Davies and Mann (1948a) reported some preliminary radiological evidence on the relationship between tuberculosis and massive fibrosis in pneumokoniosis ; the results which are now to be reported consist of an extension and elaboration of this earlier inquiry.

\section{TERMINOLOGY}

Pneumokoniosis.-The terminology used will be that used by the Pneumokoniosis Research Unit (Davies and-Mann, 1948b ; Fletcher, Mann, Davies, Cochrane, Gilson, and Hugh-Jones, 1949). In this a distinction is made between simple pneumokoniosis in which the radiographs show generalized opacities and in which four categories of increasing severity, numbered 1 to 4 , are distinguished, and complicated pneumokoniosis in which there are, in addition to the generalized opacities of simple pneumokoniosis, larger localized opacities which almost always progress in the course of a few years to the formation of massive shadows. These localized abnormalities are called progressive massive fibrosis.

Tuberculosis.- "Prevalence rate" will be used to indicate the percentage of a given population at a given time who show evidence of clinically significant tuberculosis in their chest radiographs.

"Attack rate" will be used to mean the percentage of a given population who develop radiological evidence of tuberculosis within a given period. Allowance may be made for varying intervals between radiographs in a group of cases by summing all the intervals and giving the number of cases developing tuberculous shadows per 1,000 years of combined interval or per 1,000 case-years. In doing this certain assumptions are made which render the calculated rate for 1,000 caseyears less precise than the crude rates, so that statistically significant differences are unlikely to be found where the crude percentages are not significantly different. The purpose of giving the figures for the attack rate per 1,000 case-years is to indicate how far differences in the crude percentages might be attributable to the different distribution of intervals in the various groups.

"Progression rate" means the percentage of cases that show radiological progression within a given time.

Throughout this paper the type of tuberculosis referred to is the reinfection type. "Of clinical significance," when applied to this type of disease, means that a patient with such a radiological appearance would in normal clinical practice at least be asked to return for re-examination within three or six months on radiological grounds alone.

\section{MATERIAL}

The material consisted of a large number of radiographs of coal miners, all of whom had had radiographs taken on two or more occasions at intervals of more than a year and whose industrial history during this interval was known. Some of these men were certified cases of pneumokoniosis who had been selected for an 
inquiry into the progression of this disease in the absence of dust exposure (Stewart, 1948). Others were men who had previously had radiographs taken by Hart and Aslett (1942) and were re-examined by the Pneumokoniosis Research Unit in 1946-7 in order to study the effect of further dust exposure on the progression of their disease (Davies, Fletcher, Mann, and Stewart, 1948). A further small group were cases who had been seen as in-patients for the study of methods of rehabilitation and treatment of pneumokoniosis.

The basis for the selection of all these cases had been chiefly the stage of pneumokoniosis shown in the initial radiograph, so that the material should be unbiased in relation to the development of tuberculosis and should be suitable for a study of the relationship between tuberculosis and pneumokoniosis. There was, however, a small group of cases among the men previously examined by Hart and Aslett whose initial radiograph showed the presence of tuberculous shadows, and these men had been deliberately selected for re-examination: their inclusion makes the material unsuitable for the study of the prevalence of tuberculosis in the population.

It is important to remember that the material inevitably consisted of " survivors," for only men who were still alive could be selected for re-examination. This fact might be expected to bias the results in an unduly favourable direction. However, we shall be chiefly concerned with the early stages of pneumokoniosis and of tuberculosis ; and an investigation carried out into the causes of death of men with simple pneumokoniosis selected for re-examination but found to have died in the interval since the first examination showed that in the majority of cases the cause of death was non-respiratory, and in none was tuberculosis the cause of death, so that this factor is not likely to have distorted the results seriously.

In all, there were 1,514 pairs of radiographs. In 139 pairs the first showed the presence of a tuberculous shadow " of clinical significance," and these 139 were used for the study of the progression rate of tuberculosis. The remaining 1,375 pairs were used for the study of the attack rate of tuberculosis.

\section{MeTHODS}

The films were all read by the author. For each film the category of simple pneumokoniosis $(1,2,3$, or 4$)$ and the presence or absence of complicated pneumokoniosis was noted. The primary type and healed inactive reinfection type of tuberculosis were ignored.

It is important at this stage to consider the errors which may have arisen in the radiological diagnosis of tuberculosis, for the whole inquiry is based on the assumption that the radiological abnormalities read as " reinfection type tuberculosis" were in fact caused by pathological changes initiated by the tubercle bacillus. This assumption is used daily in every hospital and tuberculosis clinic in the country, but this does not mean that it is justified, especially in films which also show the generalized mottling of pneumokoniosis. The finding of tubercle bacilli in the sputum would, of course, prove the diagnosis, but the sort of cases with which we are concerned are not those in which bacilli are often found in the sputum. Moreover, since many of the films were several years old, this procedure would have been impracticable. The other possible source of support would be a detailed statistical study of cases in which radiographs had been taken shortly before death 
and for which post-mortem findings were available. So far as it is known this has never been carried out either in cases of pneumokoniosis or in normal subjects but, on the other hand, there has been no report of any long series of discrepancies among the numerous necropsies that have been performed on tuberculous cases. On the whole, the assumption that the shadows considered to be due to tuberculosis were in fact tuberculous in origin seems not unreasonable.

There are other potential sources of diagnostic error that remain to be investigated.

It is necessary to know the consistency with which the diagnosis of tuberculous shadows could be made by the author, for Birkelo, Chamberlain, Phelps, Schools, Zacks, and Yerushalmy (1947) have shown the existence of grave inconsistencies in the radiological diagnosis of tuberculosis. Table I shows the results of duplicate readings which I carried out on a group of films collected by a colleague containing an unknown proportion of normal and tuberculous cases. The second reading was made one week after the first without knowledge of the previous opinion given on the film. The results show that so far as the reading of "clinically significant tuberculosis" is concerned I was capable of reasonable consistency.. Errors arose chiefly in the reading of the small number of cases of inactive healed tuberculosis.

TABLE I

Results of Two Readings of a Group of Films

\begin{tabular}{|c|c|c|c|c|c|}
\hline & & \multicolumn{3}{|c|}{ Diagnosis on Second Reading } & \multirow[b]{2}{*}{ Total } \\
\hline & & Normal & \begin{tabular}{|c|} 
Clinically \\
Significant \\
Tuberculosis
\end{tabular} & \begin{tabular}{|c|} 
Healed or \\
Inactive \\
Tuberculosis
\end{tabular} & \\
\hline \multirow{4}{*}{$\begin{array}{l}\text { Diagnosis on } \\
\text { first reading }\end{array}$} & Normal & $60^{*}$ & 1 & 4 & 65 \\
\hline & $\begin{array}{c}\text { Clinically significant } \\
\text { tuberculosis }\end{array}$ & 0 & 22 & 0 & 22 \\
\hline & $\begin{array}{c}\text { Healed or inactive } \\
\text { tuberculosis }\end{array}$ & $\mathbf{0}$ & 0 & 2 & 2 \\
\hline & Total & 60 & 23 & 6 & 89 \\
\hline
\end{tabular}

* The numbers in the diagonal squares are those in which the diagnosis on the two occasions was the same.

It is necessary to know whether shadows due to simple pneumokoniosis, complicated pneumokoniosis, and tuberculosis could be consistently distinguished. To investigate this point a colleague selected 209 of the 1,514 radiographs showing these three types of appearance, and I re-read them without knowing the results of his previous readings in the course of the main investigation. Table II shows the results of this experiment. It will be seen that the second diagnosis differs from the first in only 16 of the 209 films, or $8 \%$. The chief error was the overlooking on the second occasion of $5 \%$ of the cases diagnosed as tuberculosis and $5 \%$ of those diagnosed as complicated pneumokoniosis on the first reading. It is unlikely that so small an error of inconsistency would seriously influence the results that are to be reported.

It is necessary to know whether the radiological distinction between the opacities of early complicated pneumokoniosis and tuberculosis corresponds with a real difference in their underlying pathological nature. The distinction between these two 
types of radiographic appearance is not always easy, but it can usually be made with reasonable consistency, as has already been shown in Table II. (See Davies and Mann, 1948a, and Fletcher and others, 1949, for a description of the characteristic radiological appearances of early complicated pneumokoniosis.) Since post-mortem findings were not available to justify the distinction, follow-up results must suffice. A preliminary study of the different progression of cases of early complicated pneumokoniosis and of tuberculosis diagnosed radiologically has already been published (Davies and Mann, 1948a), but the point was reinvestigated. A colleague

TABLE II

Results of Two Readings of Films showing Simple and Complicated PNeumokoniosis AND TUBERCULOSIS

\begin{tabular}{|c|c|c|c|c|c|}
\hline & & \multicolumn{3}{|c|}{ Diagnosis on Second Reading } & \multirow{2}{*}{ Total } \\
\hline & & $\begin{array}{c}\text { Simple } \\
\text { Pneumokoniosis }\end{array}$ & $\begin{array}{c}\text { Complicated } \\
\text { Pneumokoniosis }\end{array}$ & Tuberculosis & \\
\hline \multirow{3}{*}{$\begin{array}{l}\text { Diagnosis } \\
\text { on } \\
\text { first } \\
\text { reading }\end{array}$} & Simple pneumokoniosis & 39 & 1 & 1 & 41 \\
\hline & $\begin{array}{ccc}\text { Complicated } & \text { pneumo- } \\
\text { koniosis } & \ldots & . .\end{array}$ & 5 & $85^{*}$ & 3 & 93 \\
\hline & Tuberculosis ... & 4 & 2 & 69 & 75 \\
\hline & Total & 48 & 88 & 73 & 209 \\
\hline
\end{tabular}

* The numbers in the diagonal squares are those in which the diagnosis was the same on the two occasions.

selected 64 pairs of radiographs belonging to 64 patients in whom early localized shadows had been diagnosed during the main investigation in the first film of each pair. The 128 films were placed in random order, and I classified them into simple pneumokoniosis, complicated pneumokoniosis, and tuberculosis, without knowing which radiograph was in fact the pair of which. The results are shown in Table III. It will be seen that, of the 33 cases in which a diagnosis of tuberculosis was made in the first film, four were not diagnosed in the second film-i.e., they were either missed or had healed. Two had apparently developed complicated pneumokoniosis in the second films, but $27(82 \%)$ were still identified in the second film as tuber-

TABLE III

Diagnosis on First and Second Films of Pairs of Radiographs from 64 Cases

\begin{tabular}{|c|c|c|c|c|c|}
\hline & & \multicolumn{3}{|c|}{ Diagnosis on Second Film of Pair } & \multirow{2}{*}{ Total } \\
\hline & & $\begin{array}{c}\text { Simple } \\
\text { Pneumokoniosis }\end{array}$ & $\begin{array}{c}\text { Complicated } \\
\text { Pneumokoniosis }\end{array}$ & Tuberculosis & \\
\hline \multirow{2}{*}{$\begin{array}{l}\text { Diagnosis } \\
\text { on first } \\
\text { film of } \\
\text { pair }\end{array}$} & $\begin{array}{cc}\text { Complicated pneumo- } \\
\text { koniosis }\end{array}$ & - & 29 & 2 & 31 \\
\hline & Tuberculosis ... & 4 & 2 & 27 & 33 \\
\hline & Total & 4 & 31 & 29 & 64 \\
\hline
\end{tabular}


culous. On the other hand, of the 31 cases in which a diagnosis of complicated pneumokoniosis had been made in the first film, 29 (94\%) showed the appearance of complicated pneumokoniosis in the second film, mostly in the form of advanced massive shadows, and only $2(6 \%)$ had now the appearance of tuberculosis. This study showed that my radiological distinction between early complicated pneumokoniosis and tuberculosis was justified by the different subsequent progression of these two types of shadows.

\section{RESULTS}

The Attack Rate of Reinfection Type Tuberculosis.-Table IV gives the attack rate of tuberculosis in relation to the category of pneumokoniosis in the first radiograph. The overall attack rate in those miners whose first radiograph was normal is $2.5 \%$. It rises to $5.8 \%$ in those whose first radiograph was in Category 1 or 2 simple pneumokoniosis, then drops to $3.3 \%$ in those with the first radiograph of Category 3 or 4 simple pneumokoniosis and finally to nil in those with complicated pneumokoniosis. These differences are significant $(P<0.001)$. These attack rates are,

TABLE IV

attack Rate of Tuberculosis and Progressive Massive Fibrosis Related to PNEUMCKONIOSIS DiagnOSED IN THE First RADIOGRAPH

\begin{tabular}{|c|c|c|c|c|c|c|c|}
\hline $\begin{array}{l}\text { Diagnosis in } \\
\text { First Radiograph }\end{array}$ & $\begin{array}{l}\text { Number } \\
\text { of } \\
\text { Cases }\end{array}$ & $\begin{array}{c}\text { Number } \\
\text { Develop- } \\
\text { ing } \\
\text { Tuber- } \\
\text { culosis }\end{array}$ & $\begin{array}{c}\text { Percen- } \\
\text { tage } \\
\text { Develop- } \\
\text { ing } \\
\text { Tuber- } \\
\text { culosis }\end{array}$ & \begin{tabular}{|c|} 
Tuber- \\
culosis \\
Attack \\
Rate \\
per 1,000 \\
Case-years
\end{tabular} & $\begin{array}{c}\text { Number } \\
\text { Develop- } \\
\text { ing } \\
\text { P.M.F. }\end{array}$ & $\begin{array}{l}\text { Percen- } \\
\text { tage } \\
\text { Develop- } \\
\text { ing } \\
\text { P.M.F. }\end{array}$ & $\begin{array}{c}\text { P.M.F. } \\
\text { Attack } \\
\text { Rate } \\
\text { per 1,000 } \\
\text { Case- } \\
\text { years }\end{array}$ \\
\hline . $\quad \ldots$ & 118 & 3 & 2.5 & 3.5 & 1 & 0.9 & 1.2 \\
\hline $\begin{array}{l}\text { Simple pneumokoniosis } \\
\text { categories } 1 \text { and } 2 \text {. }\end{array}$ & 380 & 22 & 5.8 & 8.5 & $\dot{4} 1$ & 10.8 & 16 \\
\hline $\begin{array}{c}\text { Simple pneumokoniosis } \\
\text { categories } 3 \text { and } 4 . .\end{array}$ & 335 & 11 & 3.3 & 5.3 & 113 & 34 & 54.5 \\
\hline $\begin{array}{c}\text { Complicated pneumo- } \\
\text { koniosis }\end{array}$ & 542 & 0 & 0 & 0 & 0 & 0 & 0 \\
\hline Total & 1,375 & 36 & 2.6 & 4.6 & 155 & 11.2 & 20 \\
\hline
\end{tabular}

P.M.F. $=$ Progressive massive fibrosis.

however, crude attack rates for the whole group, making no allowance for the varying intervals between radiographs of the cases falling in the various groups. To allow for this the annual attack rate per 1,000 case-years has also been calculated. These rates show a similar relationship to the original category of simple pneumokoniosis.

This relationship between the attack rate of tuberculosis and the category of simple pneumokoniosis is also shown when the attack rate is analysed in relation to the category of simple pneumokoniosis in the second radiograph (Table V). In this case the attack rate is also calculated on the basis of 1,000 patient-years. It is found to be be 3.2 in those whose second radiograph was normal, and it rises to 
TABLE $\mathrm{V}$

Attack Rate of Tuberculosis Related to Pneumokoniosis Diagnosed in the Second RADIOGRAPH

\begin{tabular}{|c|c|c|c|c|}
\hline $\begin{array}{l}\text { Diagnosis in } \\
\text { Second Radiograph }\end{array}$ & $\begin{array}{l}\text { Number of } \\
\text { Cases }\end{array}$ & $\begin{array}{l}\text { Number } \\
\text { Developing } \\
\text { Tuberculosis }\end{array}$ & $\begin{array}{l}\text { Percentage } \\
\text { Developing } \\
\text { Tuberculosis }\end{array}$ & $\begin{array}{c}\text { Rate per } \\
1,000 \\
\text { Case-years }\end{array}$ \\
\hline $\begin{array}{lllll}\text { Normal } & \ldots & \ldots & \ldots & \ldots\end{array}$ & 88 & 2 & 2.3 & 3.2 \\
\hline $\begin{array}{crr}\text { Simple pneumokoniosis } & \text { cate- } \\
\text { gories } 1 \text { and } 2 \ldots & . & . \\
\end{array}$ & 323 & 15 & 4.6 & 6.5 \\
\hline $\begin{array}{c}\text { Simple pneumokoniosis } \\
\text { gories } 3 \text { and } 4 \ldots \\
\text { cate- }\end{array}$ & 267 & 17 & 6.4 & 9.9 \\
\hline Complicated pneumokoniosis .. & 697 & 2 & 0.3 & 0.6 \\
\hline Total & 1,375 & 36 & 2.6 & 4.5 \\
\hline
\end{tabular}

9.9 in cases with Category 3 or 4 simple pneumokoniosis but is again very low in cases with complicated pneumokoniosis. These differences are also significant $(\mathrm{P}<0.001)$.

The influence of dust inhalation during the interval between radiographs was examined by comparing the attack rate of tuberculosis in the patients who had continued to be exposed to the inhalation of dust in their work in the interval between radiographs with that in those who had no such exposure during the interval (Table VI). Cases with complicated pneumokoniosis in the first radiograph were excluded in view of the absence of any attack rate of tuberculosis in them. There is no significant difference between the two crude attack rates $(P>0.05)$. The attack rate per 1,000 case-years is also similar in the two groups. This finding suggests that the increased attack rate in cases with simple pneumokoniosis is related to the presence of the disease rather than to mere dust inhalation.

TABLE VI

Attack Rate of Tuberculosis in Cases With and Without Dust Exposure in the INTERVAL BETWEEN RADIOGRAPHS

\begin{tabular}{|c|c|c|c|c|}
\hline Dust Exposure & $\begin{array}{l}\text { Number of } \\
\text { Cases }\end{array}$ & $\begin{array}{l}\text { Number } \\
\text { Developing } \\
\text { Tuberculosis }\end{array}$ & $\begin{array}{l}\text { Percentage } \\
\text { Developing } \\
\text { Tuberculosis }\end{array}$ & $\begin{array}{c}\text { Attack Rate } \\
\text { per } 1,000 \\
\text { Case-years }\end{array}$ \\
\hline No dust exposure in interval & 217 & 6 & 3 & 4.9 \\
\hline Dust exposure in interval & 616 & 30 & 5 & 6.9 \\
\hline Total & 833 & 36 & 4 & 6.5 \\
\hline
\end{tabular}

The relationship between tuberculosis and simple pneumokoniosis was explored in another way by finding the proportion of men who had shown progression of simple pneumokoniosis in the interval, classified into the following groups: $(a)$ those without tuberculosis in either radiograph; $(b)$ those without tuberculosis in the first radiograph but who had developed it in the second radiograph ; and (c) those with tuberculosis in both radiographs (Table VII). It will be seen that the pro- 
portion of men showing progression of simple pneumokoniosis was greater in those who developed tuberculosis during the interval and greatest in those who had already developed it at the beginning of the interval. The fact that the progression of simple pneumokoniosis is most marked in those with pre-existing tuberculosis is probably due to a higher prevalence of tuberculosis in collieries where there are higher concentrations of dust and thus higher progression rates of simple pneumokoniosis.

TABLE VII

Progression of Simple Pneumokoniosis in Cases With and Without Tuberculosis

\begin{tabular}{c|c|c|c|c}
\hline Radiological Diagnosis & $\begin{array}{c}\text { Number of } \\
\text { Cases }\end{array}$ & $\begin{array}{c}\text { Cases } \\
\text { Showing } \\
\text { Progression } \\
\text { of Simple } \\
\text { Pneumokoniosis }\end{array}$ & $\begin{array}{c}\text { Percentage } \\
\text { Showing } \\
\text { Progression } \\
\text { of Simple } \\
\text { Pneumokoniosis }\end{array}$ & $\begin{array}{c}\text { Mean Years } \\
\text { Dust Exposure } \\
\text { in Interval }\end{array}$ \\
\hline $\begin{array}{c}\text { Cases with no tuberculosis } \\
\text { in 1st or 2nd radiograph.. }\end{array}$ & 371 & 55 & 15 & 5.4 \\
\hline $\begin{array}{c}\text { Cases with tuberculosis in } \\
\text { 2nd radiograph only }\end{array}$ & 27 & 11 & 40 & 5.3 \\
\hline $\begin{array}{c}\text { Cases with tuberculosis in } \\
\text { both radiographs }\end{array}$ & 29 & 15 & 52 & 4.8 \\
\hline
\end{tabular}

Two other factors remain to be considered which might have influenced this association of simple pneumokoniosis and tuberculosis. First, we must consider the influence of age. Table VIII shows the attack rate of tuberculosis in the patients who were over and in those who were under the age of 40 at the time of the first radiograph. The attack rate per 1,000 case-years is the same in the two groups. Secondly, the economic status of the men must be considered. In the

TABLE VIII

Attack Rate of Tuberculosis in Cases Without Complicated Pneumokoniosis in Relation to AgE

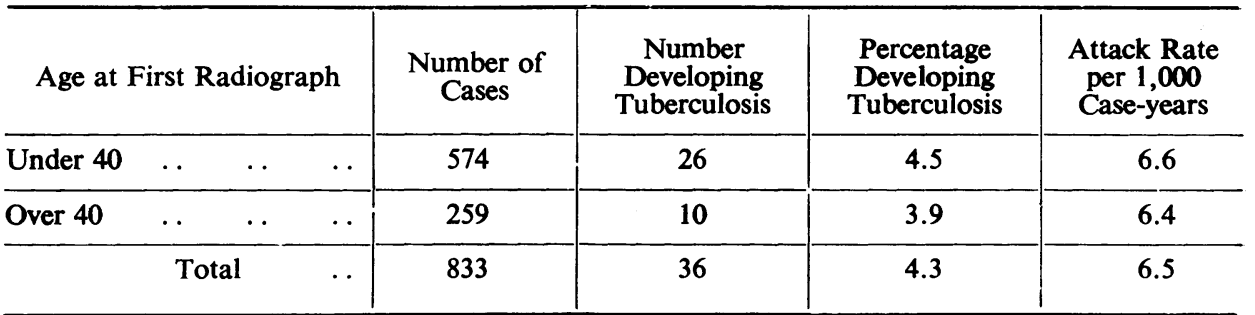

group of cases we are considering, those without exposure to dust in the interval between radiographs were predominantly men who had been certified and had therefore left the industry. Many of these men remained unemployed (Hugh-Jones and Fletcher, 1951); they had to exist on compensation and therefore had a lower economic status than those who continued at work in the mines. In spite of this there is no significant difference in the attack rate of tuberculosis in the two groups of men (Table VI). 
It is difficult to imagine that a localized disease such as the reinfection type of tuberculosis could affect the progression and development of simple pneumokoniosis. The most probable conclusion to be drawn from the discovery of a higher attack rate of tuberculosis in men with simple pneumokoniosis is that in some way the presence of dust in the lung facilitates the radiological appearance of tuberculosis.

The lower attack rate of tuberculosis in those with Category 3 or 4 simple pneumokoniosis compared with those with Category 1 or 2 simple pneumokoniosis, and the absence of any attack rate in men who had complicated pneumokoniosis in the first radiograph, will be discussed later.

Progression of Tuberculosis in Relation to Simple Pneumokoniosis.-The progression of tuberculous lesions was studied by comparing the second radiograph taken between one and ten years later with the first in 139 cases with tuberculous shadows in the first radiograph. The distribution of the severity and type of the associated pneumokoniosis is given in Table IX. One hundred and thirty-one of

TABLE IX

Severity and Type of Associated Pneumokoniosis in 139 Cases With TUBerculous Lesions IN First Radiograph

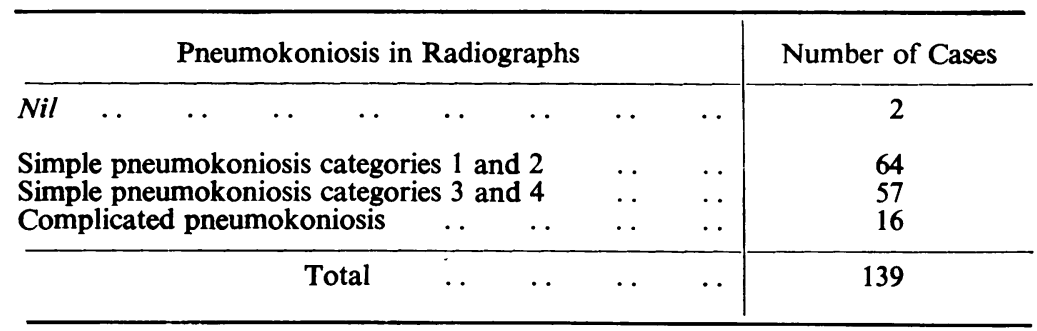

these lesions retained their tuberculous appearance in the second radiograph, whereas eight $(6 \%)$ changed their character to produce typical massive shadows of complicated pneumokoniosis. Of those which retained their tuberculous character, $54 \%$ advanced, but only $8 \%$ to a moderate or marked degree (mean observation period five years). Reisner (1948), who followed up 300 early tuberculous lesions in nonminers, reported that $75 \%$ advanced, $51 \%$ showing moderate or marked progression (mean observation period 3.5 years). Although it is difficult to be sure that "progression" meant exactly the same thing in his study, the apparently low progression rate observed in miners might be due either to the fact that many of them had simple pneumokoniosis or to their exposure to the inhalation of coal dust.

The observation that $6 \%$ of typical tuberculous lesions in the presence of advanced simple pneumokoniosis progresses into progressive massive fibrosis is an important one. It must be considered in relation to the observation that the attack rate of tuberculosis was nil in men with complicated pneumokoniosis in the first radiograph and was low in those with complicated pneumokoniosis in the second radiograph, and that the prevalence rate in cases with complicated pneumokoniosis in the first radiograph was also low.

There are two possible explanations for these observations. First, the shadows cast by the massive fibrosis in complicated pneumokoniosis might hide those of 
tuberculosis by simple superimposition. It is, however, difficult to imagine that shadows of 452 cases of complicated pneumokoniosis would all coincide with those of new or existing tuberculous lesions. Alternatively, and more likely, it may be suggested that progressive massive fibrosis itself may be a modified form of tuberculosis. This seems the simplest explanation of the observations that have been described, and some support is given to it by pathological evidence (Belt and Ferris. 1942 ; Gough, 1947).

The fact that the attack rate of tuberculosis was found to be lower in cases with Category 3 and 4 simple pneumokoniosis than in those with Category 1 or 2 simple pneumokoniosis in the first radiograph may also be explained by the suggestion that in the presence of more advanced simple pneumokoniosis a larger proportion of tuberculous infections become modified from the outset into the tormation of progressive massive fibrosis. In Table IV the "attack rate" of progressive massive fibrosis is also given. It is seen to be very low in cases with a normal first radiograph. (The single patient noted here developed simple pneumokoniosis in the interval.) It is $10.8 \%$ in those with early simple pneumokoniosis (Category 1 and 2), ${ }^{*}$ and it rises to $34 \%$ in those with advanced simple pneumokoniosis (Category 3 and 4). Where the attack rate of tuberculosis is considered only in relation to the second radiograph (Table $\mathrm{V}$ ) this disturbing influence is avoided because all cases of complicated pneumokoniosis are separately considered, and we then find a higher attack rate in cases with more advanced simple pneumokoniosis.

Of the total number of localized shadows (tuberculosis or progressive massive fibrosis) developing in cases with Category 3 or 4 simple pneumokoniosis in the first radiograph, $91 \%$ are progressive massive fibrosis and only $9 \%$ are tuberculous, whereas in cases with Category 1 and 2 simple pneumokoniosis in the first radiograph $65 \%$ are progressive massive fibrosis and $35 \%$ are tuberculous. Thus the apparent attack rate of unmodified tuberculosis may be reduced in cases of Category 3 and 4 simple pneumokoniosis owing to a large number of tuberculous infections having become modified to form progressive massive fibrosis.

Prevalence of Tuberculosis in Miners.-The material used in this investigation was unsuitable for the calculation of prevalence rates, since the original selection had a bias in favour of selecting cases with tuberculous shadows in the first radiograph. Evidence on this question is, however, available from radiological surveys carried out by Hart and Aslett in 1937 at an anthracite colliery in South Wales, and by the Pneumokoniosis Research Unit at two collieries, one steam coal colliery in South Wales and one bituminous coal colliery in England (Cochrane, 1949). $\dagger$ Radiographs taken in these surveys were read by a colleague and by me. The results are given in Table X. It will be seen that the prevalence of tuberculosis in miners with no radiographic evidence of pneumokoniosis is 5-6\%. Prevalence rates in the non-mining population of South Wales are not available for comparison. In the general population of England they are stated to be $0.25 \%$ by Dudley (1941), $0.82 \%$ by Brooks (1946), and $1.3 \%$ by Clark, Hart, Kerley, and Thompson (1945). In America, Bloch, Francis, Eisele, and Mason (1938) give the prevalence rate in about 1,000,000 persons

* In all but five of the 41 cases in Categories 1 and 2 which developed complicated pneumokoniosis, the category of simple pneumokoniosis progressed to Category 3 in the interval between the radiographs.

$\dagger$ The age distribution of the workers at these collieries was almost identical. 
TABLE $X$

Prevalence of Simple Pneumokoniojis* (Categories 1-4) and Tuberculosis in Radiographs of Underground Population of Three British Coal Mines

\begin{tabular}{|c|c|c|c|c|c|c|c|}
\hline \multirow{2}{*}{ Mine } & \multicolumn{2}{|c|}{ Simple Pneumokoniosis } & \multicolumn{3}{|c|}{$\begin{array}{l}\text { Radiological Evidence } \\
\text { of Tuberculosis }\end{array}$} & \multirow{2}{*}{$\begin{array}{c}\text { Men With } \\
\text { Pneumo- } \\
\text { koniosis } \\
(\%)\end{array}$} & \multirow{2}{*}{$\begin{array}{c}\text { Men With } \\
\text { Tuber- } \\
\text { culosis } \\
(\%)\end{array}$} \\
\hline & $\begin{array}{c}\text { Radiological } \\
\text { Diagnosis }\end{array}$ & $\begin{array}{l}\text { No. of } \\
\text { Cases }\end{array}$ & Active & Inactive & Total & & \\
\hline \multirow{3}{*}{$\begin{array}{l}\text { Wales } \\
\text { (anthracite) }\end{array}$} & Absent & 150 & 4 & 3 & $7(5 \%)$ & \multirow{3}{*}{62} & \multirow{3}{*}{11} \\
\hline & Present & 249 & 27 & 10 & $37(15 \%)$ & & \\
\hline & Total & 399 & 31 & 13 & 44 & & \\
\hline \multirow{3}{*}{$\begin{array}{l}\text { Wales } \\
\text { (steam coal) }\end{array}$} & Absent & 218 & 6 & 7 & $13(6 \%)$ & \multirow{3}{*}{46} & \multirow{3}{*}{10} \\
\hline & Present & 188 & 19 & 10 & $29(15 \%)$ & & \\
\hline & Total & 406 & 25 & 17 & 42 & & \\
\hline \multirow{3}{*}{$\begin{array}{l}\text { England } \\
\text { (bituminous) }\end{array}$} & Absent & 727 & 24 & 11 & $35(5 \%)$ & \multirow{3}{*}{27} & \multirow{3}{*}{5} \\
\hline & Present & 264 & 12 & 5 & $17(6.5 \%)$ & & \\
\hline & Total & 991 & 36 & 16 & 52 & & \\
\hline
\end{tabular}

* Cases of complicated pneumokoniosis excluded.

as $1.5 \%$, while Edwards (1940) reports it as $2 \%$ in 130,000 New York citizens. The prevalence in normal miners appears higher than that reported by these various observers if our diagnostic criteria were the same as theirs. It is similar to that reported by Cummings, Downs, and Berg (1939) in male industrial workers in the U.S.A. It will be seen in Table $X$ that the prevalence in miners tends to rise further in the presence of simple pneumokoniosis, so that the total prevalence in the pit appears related in some way to the prevalence of simple pneumokoniosis. This observation is confirmed by results of surveys made in America. The prevalence of pneumokoniosis in bituminous coal miners in America is low, and so is that of tuberculosis (Clarke and Moffet, 1941 ; Flinn, Seifert, Brinton, Jones, and Franks, 1941). On the other hand, the presence of pneumokoniosis in anthracite coal miners in America is high ; so is the prevalence of tuberculosis (Bloomfield, DallaValle, Jones, Dreessen, Brundage, and Britten, 1935). It will also be noted in Table IX that the prevalence of tuberculosis in cases with complicated pneumokoniosis is low, which confirms the observation made in the earlier part of this paper.

Since the prevalence rate of tuberculosis varies directly with the attack rate, but inversely with the mortality rate, it is not surprising to find a high prevalence rate in miners ; for a high attack rate in cases of simple pneumokoniosis has been demonstrated in the earlier part of this paper, and it is well known that miners have a low tuberculosis mortality rate.

\section{Discussion}

It remains to be seen whether any hypothesis can be proposed to explain the modifications that have been shown to occur in the attack and progression rates of tuberculosis in cases of simple pneumokoniosis and to explain the suggestion that 
progressive massive fibrosis is in itself a modified form of tuberculosis occurring in a lung already affected by simple pneumokoniosis.

Experimentally it has been shown that the productive tissue reaction to the intratracheal inoculation of anthracite dust and killed human tubercle bacilli is greater than that which occurs if either is injected alone (Cummins, 1940). It has also been shown that if anthracite dust is mixed with tuberculin the subsequent intradermal reaction on the injection of tuberculin is inhibited (Cummins, Weatherall, and Waters, 1931). It is, therefore, possible that small quantities of coal dust in the lung (simple pneumokoniosis Categories 1 and 2) absorb the products (? lipoid) of the tubercle bacilli which cause caseation, thus clearing the way for fibrosis or actually stimulating it, for even in the absence of infection coal dust causes some fibrosis in the lung (Heppleston and Gloyne, 1949). When coal is present in larger amounts (simple pneumokoniosis Categories 3 and 4) it may overstimulate fibrosis in association with tuberculous infection to such an extent that the massive fibrosis characteristic of complicated pneumokoniosis is produced.

The reason why, in cases with simple pneumokonoisis, tuberculosis may sometimes retain its normal radiological appearance while in the majority it is greatly modified (Table IV) remains to be explained. It is remarkable that in some cases (Table IX) a normal tuberculous appearance may be seen in one lung field, while in the other a shadow characteristic of progressive massive fibrosis appears. The modification may be dependent on the initial location of the tuberculous infection in relation to the foci of dust deposition in the lung.

If in the presence of a small amount of coal dust in the lungs a more fibrous type of tuberculous lesion is produced than in a normal lung, it is possible that the higher attack rate of radiologically diagnosed tuberculosis which has been found in cases of simple pneumokoniosis is not due to a higher infection rate but to a higher proportion of lesions becoming sufficiently radio-opaque to be diagnosed radiologically than in cases with normal lungs.

The observations on the attack, prevalence, and progression rates of tuberculosis in miners which have been recorded in this paper can only be considered as preliminary. The hypothesis that coal dust exerts a modifying influence on the development of tuberculosis in the lung is very far from being established. It is a hypothesis of considerable interest, and it is hoped that the evidence presented here may stimulate further radiological and experimental investigations.

\section{Summary}

A study of the development and progression of tuberculous shadows in the radiographs of coal miners is reported. It is suggested that the radiological diagnosis of tuberculosis in such radiographs can be made with reasonable consistency, and that shadows characteristic of tuberculosis can be distinguished in radiographs from those characteristic of simple and complicated pneumokoniosis.

The attack rate of the reinfection type of tuberculosis is found to be related to the severity of the associated simple pneumokoniosis. It is apparently reduced in cases of complicated pneumokoniosis.

The progression rate of tuberculosis in the presence of simple pneumokoniosis is apparently retarded. 
The prevalence of tuberculosis, diagnosed radiologically, appears to be higher among miners with simple pneumokoniosis than in the general population. This high prevalence is related to the higher attack rate and lower progression and mortality rates from tuberculosis in miners compared with the normal population.

It is suggested that progressive massive fibrosis, characteristic of complicated pneumokoniosis, may be a modified form of tuberculosis, in which the fibrogenic action of the tubercle bacillus is stimulated by some action of the coal dust while the caseating action is inhibited.

I should like to thank all my colleagues in the Pneumokoniosis Research Unit for helpful criticisms, Dr. C. M. Fletcher and Dr. A. L. Cochrane for their assistance in the preparation of this paper, and Mr. P. D. Oldham for his statistical examination of my findings.

\section{REFERENCES}

Belt, T. H., and Ferris, A. A. (1942). Spec. Rep. Ser. med. Res. Coun., Lond., No. 243.

Birkelo, C. C. Chamberlain, W. E., Phelps, P. S., Schools, P. E., Zacks, D., and Yerushalmy, J. (1947). J. Amer. med. Ass., $133,359$.

Bloch, R. G., Francis, B. F., Eisele, C. W., and Mason, E. W. (1938). Amer. Rev. Tuberc., 37, 174. Bloomfield, J. J., DallaValle, J. M., Jones, R. R., Dreessen, W. C., Brundage, D. K., and Britten, R. H. (1935). Publ. Hith Bull., Wash., No. 221.

Brooks, W. D. M. (1946). J. roy. nav. med. serv., 32, 197.

Clark, K. C., Hart, P. D'A., Kerley, P., and Thompson, B. C. (1945). Spec. Rep. Ser. med. Res. Coun., Lond., No. 251.

Clarke, B. G., and Moffet, C. E. (1941). J. industr. Hyg., 23, 176.

Cochrane, A. L. (1949). Unpublished.

Cummings, D. E., Downs, R. N., and Berg, M. (1939). Amer. Rev. Tuberc., 39, 439.

Cummins, S. L. (1940). Brit. J. exp. Path., 21, 64.

Weatherall, C., and Waters, E. T. (1931). J. Hyg., Camb., 31, 464.

Davies, I., Fletcher, C. M., Mann, K. J., and Stewart, A. (1948). Proc. 9th Int. Congr. Industr. Med., Lond., p. 773.

- and Mann, K. J. (1948a). In Fletcher (1948).

(1948b). Proc. 9th Int. Congr. Industr. Med., Lond., p. 769.

Dudley, S. F. (1941). Proc. roy. Soc. Med., 34, 401.

Edwards, H. R. (1940). Amer. Rev. Tuberc., 40, 41.

Fletcher, C. M. (1948). Brit. med. J., 1, 1015, 1065.

- Mann, K. J., Davies, I., Cochrane, A. L., Gilson, J. C., and Hugh-Jones, P. (1949). J. Fac. Radiol., 1, 40.

Flinn, R. H., Seifert, H. E., Brinton, H. P., Jones, J. L., and Franks, R. W. (1941). Publ. Hlth Bull., Wash., No. 270.

Gooding, C. G. (1946). Lancet, 2, 891.

Gough, J. (1947). Occup. Med., 4, 86.

Hart, P. D'A., and Aslett, E. A.'(1942). Spec. Rep. Ser. med. Res. Coun., Lond., No. 243.

Heppleston, A. G., and Gloyne, S. R. (1949). Thorax, 4, 168.

Hugh-Jones, P., and Fletcher, C. M. (1951). Med. Res. Coun. Memo., No. 25.

James, W. R. L. (1948). Unpublished.

Reisner, D. (1948). Amer. Rev. Tuberc., 57, 207.

Rogers, E. (1946). Lancet, 1, 462.

Sladden, A. F. (1947). Unpublished.

Stewart, A. (1948). Brit. J. industr. Med., 5, 120. 